\title{
Development of Macroeconomic Theory Materials Based on Blended Learning
}

\author{
Putri Sari M. J. Silaban ${ }^{1}$, Joko Suharianto ${ }^{2}$, Dede Ruslan ${ }^{3}$ \\ ${ }^{1,2,3}$ Faculty of Economics, Medan State University, Indonesia \\ poetrisilaban@yahoo.co.id
}

\section{Abstract}

The aim of the study was to produce teaching material for Macroeconomics Theory. The Research and Development $(R \& D)$ method by Borg and Gall was used in this study. The population of this study was all Economic Education Study Program's students who took Macroeconomics courses in 2019. The sample was determined by using the purposive random sampling principle Keywords

research; development; materials, macroeconomic theory and the sample class made for the implementation and limited testing of small sample was Class $C$ of Economic Education. Based on the result of the study, it was decided that the teaching material for Macroeconomics Theory that has been validated by 2 expert validators had a very high level of eligibility (88.75\%) provided revisions were needed. After it has been fully revised, the material was tested to all 30 students of Class $C$ of Economic Education during Macroeconomics Theory course. Based on the testing conducted to the small sample, it showed that there was a significant improvement of the learning outcomes before and after the blended-learning based teaching material was implemented. The result was all the user-friendliness, usability, and time effectiveness factor have an average value $\geq 4$. It can be concluded that the book being developed has met the readability and practicality criteria. The study was only conducted up to stage 7 producing the teaching material of revision draft.

\section{Introduction}

Various methods are used to improve student's competencies including innovation in learning methods and revitalization of teaching materials that are relevant to the times and technology. According to Adi (2016: 26) Lecturers as facilitators must be able to organize learning that educates. The effort made by lecturers is by utilizing technology and information (IT). Utilization is using because the world of education has begun to shift the paradigm of 21st century learning where learning from the traditional Era towards IT-based learning and the internet, so learning can be done anywhere and anytime, also information can be obtained from anywhere. The development of ICT technology allows the use of various media functions learning that is able to convey information and learning material in the form of text, images, animation, film, and even interaction. One form of learning paradigm shift is the application of traditional learning methods (face to face) with an ITbased learning model. One form of breakthrough in modern learning methods is blended learning 
Blended learning refers to a learning strategy that combines face-to-face learning and computer-based learning, both online and offline, which is carried out through e-learning (Driscoll, 2002; Graham et al., 2003; Jones, 2006; Osguthorpe \& Graham, 2003)

This method is considered relevant to the sophisticated technology and the high dependence of students with gadgets and the internet in life and learning resources. Blended learning enables students to study independently with teaching materials that have been prepared by supporting lecturers. One form of contemporary learning design is the concept of developing blended learning. Some of the results of previous studies that improve learning outcomes are Hiltz \& Murray (2005) showing that there is a significant increase in academic ability in students who use face-to-face learning combined with online and offline learning technology compared to learning that only uses conventional classes (face-to-face).

Blended learning in this research is packaged using edmodo applications. Edmodo is a social network for learning based on learning management system (LMS). Edmodo provides facilities for lecturers, students a safe place to communicate, collaborate, share content and learning applications, homework for students, discussions in virtual classrooms, online tests, provision of values, and so on. According to Dharmawati (2017) Edmodo is very comprehensive as a course management system like Moodle, the difference is that access is faster and easier to use. Edmodo has three functions in the learning process, namely substitute, companion, and complementary functions.

One effort of learning strategies that are adaptive to the role of technology is the learning strategy of blended learning. While efforts to improve student's learning outcomes, especially in the Macroeconomic Theory, are done by improving the teaching materials of the course through a series of research and development (RnD) teaching materials according to Borg \& Gall (1983, in Sugiyono, 2010). Teaching material developed based on instructional design theory plays an important role in creating conducive learning conditions. There are at least three reasons why the teaching material has a central position, namely (1) as a representation of the presentation of teaching staff, (2) as a means of achieving learning objectives, and (3) as an optimization of service to students (Zulkarnain, 2009).

The supporting lecturer team had previously made a module on macroeconomic theory, but it had not yet been traversed by the research and development $(\mathrm{RnD})$ process. Therefore, in the lecture process of macroeconomic theory courses it is deemed necessary to arrange a revitalization of the development of teaching materials that can help students understand macroeconomic theory material more easily and completely. Based on this background, a study was conducted on the development of textbooks in an effort to improve student learning outcomes in macroeconomic theory. The main objective to be achieved in this research is to produce a textbook of macroeconomic theory based on blended learning

\section{Research Method}

This research used research and development methods. The purpose of development research according to Borg \& Gall (1983) wass to develop and validate research products. The steps in this research and development were carried out as many as 10 steps with the following stages 1) potential and problems, 2) data collection, 3) product design, 4) design validation, 5) design revision, 6) product trial, 7 ) first product revision, 8) trial use, 9) second product revision and 10) mass production (Sugiyono, 2010). Due to time constraints and collided at the 8th stage, the trial use should ideally be conducted on a large sample for 1 semester, namely the fourth semester students in macroeconomic theory courses in the 
academic year 2019/2020. In this research, the research and development (R\&D) step in compiling teaching materials for macroeconomic theory only reaches the 7 th stage, namely product revision II

This research was carried out for 6 months in the Economics Education Study Program FE Unimed. Research subjects as sources of data in this study were lecturers and students of economic education. Lecturers who became the subject of this study were lecturers who took macroeconomic theory courses at FE Unimed and lecturers who were in the KDBK economic education learning program. Development of teaching materials for macroeconomic theory has good quality if it meets the aspects of validity, practicality and effectiveness.

\section{a. Validity}

In this study, the answers to the instrument items were classified into five choices. Each indicator measured was given a scale score of 1-5, i.e. 5 (very good / very appropriate / very feasible / very clear), 4 (good / appropriate / feasible / clear), 3 (not good / less suitable / less feasible / less clear), 2 (not good / inappropriate / improper / unclear), and 1 (very bad / very inappropriate / very improper / very unclear). The next step was to assess the feasibility of a teaching material to be implemented in teaching macroeconomic theory. After the data was obtained, then to see the weight of each validator's response by calculating the average score using the following formula (Ernawati and Sukardiyono, 2017):

$$
\text { Average total score }=\frac{\text { Total Soore }}{\text { Numbar of Assasors }}
$$
formula.

Then for the formula the percentage of results can be calculated with the following

$$
\text { Result }=\frac{\text { Average Total Scora }}{\text { Maximum Score }} \times 100 \%
$$

The eligibility category is based on the following criteria:

Tabel 1. Media Feasibility Criteria /Product / Teaching Material

\begin{tabular}{|c|c|l|}
\hline No & $\begin{array}{c}\text { Score in } \\
\%\end{array}$ & $\begin{array}{c}\text { Feasibility } \\
\text { Criteria }\end{array}$ \\
\hline 1 & $<21 \%$ & Very Bad \\
\hline 2 & $21-40 \%$ & Bad \\
\hline 3 & $41-60 \%$ & Enough \\
\hline 4 & $61-80 \%$ & Good \\
\hline 5 & $81-100 \%$ & Very Good \\
\hline
\end{tabular}

Source : Arikunto, 2009: 35.

\section{b. Practicality}

To test the practicality will be assessed by students to test the readability assessment of books on a limited sample of textbooks that have been made using a Likert scale. This practical test examines the readability of teaching materials in terms of ease of use (Learnability), effectiveness (Efficiency) and effectiveness of time (Effectiveness of Time). 
Later from the total value range from the resulting Likert scale will be converted to value criteria determined by the practicality level of the use of the textbook

\section{c. Effectiveness}

To test the effectiveness of these teaching materials, later trials will be carried out in a limited group with an experimental design before-after (one to one) using paired sample $\mathrm{t}$ tests. The effectiveness of teaching materials was tested on a small sample of 30 macroeconomic theory students with a hypothesis:

$\mathrm{H}_{\mathrm{o}}$ : There is no difference in learning outcomes before and after treatment using macroeconomic theory teaching materials.

$\mathrm{H}_{\mathrm{a}}$ : There are differences in learning outcomes before and after treatment using macroeconomic theory teaching materials.

With accept criteria $\mathrm{H}_{\mathrm{o}}$, if the score Sig $>0,05$ and reject $\mathrm{H}_{\mathrm{o}}$, if the score $\mathrm{Sig}<0,05$ (Kadir, 2015).

\section{Discussion}

The development of teaching materials has gone through a series of research and development that refers to Borg and Gall (1983) in Sugiyono (2010) with the following steps::

a. Potential and problems namely discussing the availability of potential studies and problems in developing macroeconomic theory teaching materials.

At this stage discussing the background of developing macroeconomic theory teaching materials commonly used by students. The results of the evaluation to students turned out to have several obstacles including the following:

1) From the results of the RPS development of macroeconomic theory courses it was known that the teaching material was spread in several books making it difficult for students to learn. The hope is that it can be easier and more efficient for more integrated learning resources according to the material needed. Therefore, it was necessary to design a book that is more comprehensive and in accordance with the RPS material used.

2) The Previous macro-economic theory books were prepared, but they had not yet gone through a process of further R\&D research studies, so research and development of these teaching materials needs to be held.

b. Collecting data namely the availability of information that can be used for planning the preparation of products of macroeconomic theory teaching materials which in this study were:

1) RPS standardization document for macroeconomic theory subject

2) Concept document $6 \mathrm{KKNI}$ assignments for macroeconomic theory subject

3) Document assessment instruments for learning outcomes of macroeconomic theory

In addition, this data collection included 4 analyzes namely student analysis, material analysis and task analysis.

1) Analysis of students. Student analysis aimed to examine the characteristics of students in accordance with the design and development of textbooks. Based on the analysis results of students selected instructional media using textbooks with a 
portfolio assessment approach (6 KKNI assignments) and integrated with edmodo learning applications.

2) Material Analysis. Material analysis was used to identify the main parts to be taught and arrange them systematically in the textbook. The material that would be discussed in this research was the material on macroeconomic theory courses. Based on the results of the team's discussion the macroeconomic theory material was formulated into 12 chapters as follows:
Bab 1 Pendahuluan
Bab 2 Pendapatan Nasional
Bab 3 Penentuan Kegiatan Ekonomi
Pandangan Klasik, Keynes, \& Masa Kini
Bab 4 Keseimbangan Perekonomian Dua Sektor
Bab 5 Keseimbangan Perekonomian Tiga Sektor
Bab 6 Keseimbangan Perekonomian Terbuka
Bab 7 Permintaan dan Penawaran Agregat
Bab 8 Model Analisis IS-LM
Bab 9 Uang dan Kebijakan Moneter
Bab 10 Inflasi dan Pengangguran
Bab 11 Perdagangan Luar Negeri dan Aktivitas Ekonomi
Bab 12 Neraca Pembayaran, Kurs Valuta Asing \&

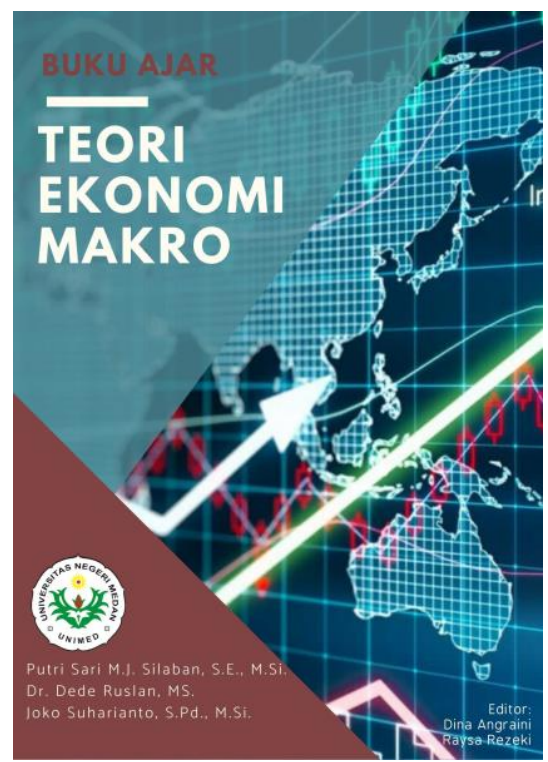

Picture 1. Table of Contents and Cover of Macroeconomic Theory Books

3) Task Analysis. Task analysis included an understanding of the tasks to be given in learning tailored to the analysis of the material. Based on the results of task analysis, assignments in learning were carried out both individually and in groups. The assignments given were designed with a portfolio assessment approach based on 6 KKNI assignments consisting of routine tasks, journal reviews, CBR, mini research, projects and idea engineering.

4) Analysis of Specifications on Learning Objectives. This analysis aimed to convert the analysis of concepts and assignments into learning objectives (Competency Standards, Basic Competencies and Competency Achievement Indicators) which were the basis in the preparation of tests and textbook design.

c. Product Design namely the availability of draft macroeconomic theory books.

At the design stage textbooks were developed based on competency standards, basic competencies and indicators of competency achievement in macroeconomic theory courses. In this study a macroeconomic theory textbook was made integrated with the Edmodo learning application. The book material is arranged in 12 chapters, each chapter consisting of a description of the subject matter of learning, examples of cases in accordance with the subject matter, and was equipped with examples of multiple choice exercise questions.

d. Design Validity namely the availability of validity test results documents.

Textbooks that had been compiled at the product design stage were then tested through several stages. The first stage was the validation test of the textbook using an expert validity assessment. The validation consisted of two stages: 1) validation questionnaire validation 
sheets that will be used by the expert team in assessing teaching materials, 2) book validation through a questionnaire given to the expert team after revision. The questionnaire validation was carried out by 2 validators who were experts in the field of macroeconomic theory. As for some experts who gave consideration to the validity of the content of macroeconomic theory textbooks (1) Dr. Arwansyah, M.Si. (Lecturer of Macroeconomic Theory Economic Study Program); dan (2) Dr. Eko Wahyu Nugrahadi, M.Si. (Supporting of Introduction to Macroeconomic Economics Education Study Program).

The following results from the validation questionnaire by the validator.

Table 1. Module Questionnaire Validation

\begin{tabular}{|c|l|l|}
\hline No & \multicolumn{1}{|c|}{ Name } & \multicolumn{1}{c|}{ Validation } \\
\hline 1 & Dr. Arwansyah, M.Si. & $\bullet$ Questionnaire score score options improved \\
\hline 2 & $\begin{array}{l}\text { Dr. EKo Wahyu } \\
\text { Nugrahadi, M.Si. }\end{array}$ & $\begin{array}{l}\bullet \text { Questions and language editors were in accordance } \\
\text { with what was being achieved }\end{array}$ \\
\hline
\end{tabular}

Source : Primary Data, processed (2019)

After the validation sheet was revised, the validator provided an assessment of the module overview. Following were the results of expert validation regarding module improvements.

Tabel 2. The Sugegstion Module Revision from the Validator

\begin{tabular}{|l|l|l|}
\hline No & Name & Validation \\
\hline 1 & $\begin{array}{l}\text { Dr. Arwansyah, } \\
\text { M.Si. }\end{array}$ & $\begin{array}{l}\text { - Layout and writing to make it more compact. } \\
\text { - Curve graphs make writing clearer than before } \\
\text { - Books needed to be equipped with RPS } \\
\text { - Concept 6 of the KKNI tasks needed to be explained } \\
\text { in detail at the end of the chapter. }\end{array}$ \\
\hline 2 & $\begin{array}{l}\text { Dr. Eko Wahyu } \\
\text { Nugrahadi, M.Si. }\end{array}$ & $\begin{array}{l}\text { Complete in each Chapter for the introduction which } \\
\text { included a) Short description, b) Relevance of data, c) } \\
\text { Study instructions, d) Formative tests (routine } \\
\text { assignments) completed with multiple choice questions } \\
\text { in the form of HOTS, e) At the end of the Chapter a } \\
\text { UTS and UAS question is made HOTS multiple choice } \\
\text { complete with answer key. }\end{array}$ \\
\hline
\end{tabular}

Source : Primary Data, processed (2019)

Some aspects observed in the textbook could be seen in Table 3. Based on the results of the consideration of the two experts on the 16 aspects observed from 12 chapters received an overall assessment as follows: 
Tabel 3. The Validity Aspect of Textbook Contents

\begin{tabular}{|c|c|c|c|}
\hline \multirow{2}{*}{ No. } & \multirow{2}{*}{ Observed aspects } & \multicolumn{2}{|c|}{ Validator } \\
\hline & & 1 & 2 \\
\hline 1 & Book is suitable with the curriculum syllabus & 5 & 5 \\
\hline 2 & Book is suitable with the expected basic competencies & 4 & 5 \\
\hline 3 & The book is relevant to the material students must learn & 5 & 5 \\
\hline 4 & The contents of the material have a correct and appropriate concept & 4 & 4 \\
\hline 5 & Book helps explain scientific concepts & 5 & 5 \\
\hline 6 & The book contains relevant sample questions & 4 & 4 \\
\hline 7 & The book contains the concept of tasks based on $6 \mathrm{KKNI}$ tasks & 4 & 4 \\
\hline 8 & $\begin{array}{l}\text { Appropriate examples of questions \& practice questions with the } \\
\text { material being studied }\end{array}$ & 4 & 5 \\
\hline 9 & $\begin{array}{l}\text { Conformity between UTS and UAS questions with material on the CBT } \\
\text { concept }\end{array}$ & 5 & 4 \\
\hline 10 & $\begin{array}{l}\text { Existing practice questions have met the proportion of the level of } \\
\text { difficulty }\end{array}$ & 5 & 4 \\
\hline 11 & The language used is good and right & 4 & 4 \\
\hline 12 & The language used is easy to understand and understand & 4 & 4 \\
\hline 13 & Appearance and composition of books & 5 & 5 \\
\hline 14 & Interesting arrangement of pictures and tables & 5 & 5 \\
\hline 15 & The font size used is clear & 4 & 5 \\
\hline 16 & Students can use books independently & 4 & 4 \\
\hline \multicolumn{2}{|c|}{ Total Score } & 71 & 72 \\
\hline \multicolumn{2}{|c|}{ Maximal Score } & 80 & 80 \\
\hline
\end{tabular}

Source : Primary Data, processed (2019)

Based on the data table above the validator value is known that the average value of the total score is $=\frac{71+72}{2}=71,5$. Then calculated using the formula for the percentage of eligibility values $=\frac{71,5}{80} \times 100 \%=88,75 \%$. Furthermore, based on the product feasibility category, the macroeconomic theory teaching material is included in the very feasible criteria, but with a note that it needs to be revised based on the validator's suggestion.

e. Design Revision namely the availability of draft design revision as a result of design validation by experts. After going through the expert validation stage, the first revision of the 
textbook draft was carried out by adjusting to the assessment of the experts so as to produce a revised edition of the macroeconomic theory textbook. The revised results of this textbook would in part be uploaded as materials for blended learning based learning by using the Edmodo application with the following display:

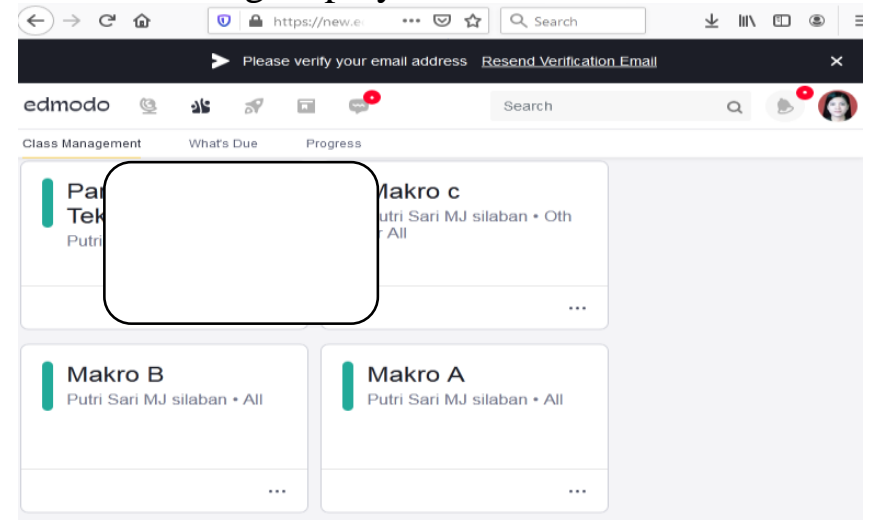

Picture 2. Edmodo-Based Learning Display

f. Product Trial that was, the result of a limited trial document in a small class sample that was chosen as a class in semester III as a class sample that is currently in a macroeconomic theory course. Before-after experimental design on the sample of money material and monetary policy in 2 meetings, the first meeting of students was given a pre-test problem and using a blended learning learning system and in the second meeting using a face-to-face learning system and also given a post test problem. Finally from the student meeting would be given a questionnaire to assess the readability of the teaching material.

The results of this small group trial use paired sample $t$ tests with the following results:

Table 4. Paired Difference Test Calculation Results

\section{Paired Samples Test}

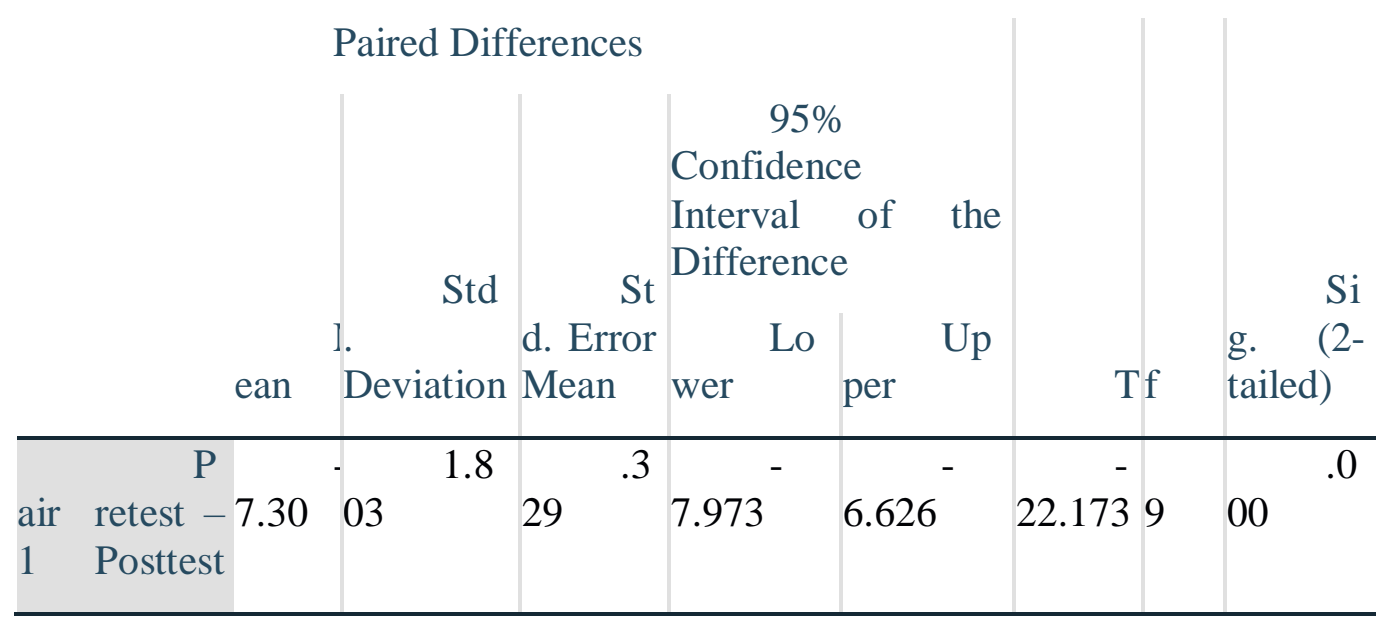

Source : Primary Data, processed (2019)

Based on the table above $\mathrm{t}$ hitung is 22,173 with Sig score is $0,000<0,05$, it can be concluded that there are differences in student learning outcomes in a small group sample before and after treatment using these textbooks. This means that teaching materials that 
have been prepared provide more tangible learning outcomes after using these teaching materials.

Furthermore, the results of the readability test assessment on a limited sample of 30 students can be seen in the following table:

Table 5. Book Readability Assessment in Limited Samples

\begin{tabular}{|c|c|c|}
\hline No & Indicator & Average \\
\hline $\mathbf{A}$ & \multicolumn{2}{|l|}{ Variable : Learnability } \\
\hline 1 & Instructions for use of teaching materials & 4.1 \\
\hline 2 & $\begin{array}{l}\text { Use of language \& sentence structure according to the level of student } \\
\text { ability }\end{array}$ & 4.1 \\
\hline 3 & Can support the learning process of individuals and groups & 4.3 \\
\hline 4 & Exercise can help students understand concepts & 4.2 \\
\hline 5 & Blended learning that is used can facilitate the learning process & 4.0 \\
\hline $\mathbf{B}$ & \multicolumn{2}{|l|}{ Variable : Efficiency } \\
\hline 1 & $\begin{array}{l}\text { Teaching materials can help students deepen understanding of the } \\
\text { material }\end{array}$ & 4.0 \\
\hline 2 & Images in teaching materials can help students find concepts & 4.1 \\
\hline 3 & Learning material is easy to understand & 4.2 \\
\hline 4 & $\begin{array}{l}\text { Assignments on teaching materials can help students in understanding } \\
\text { concepts }\end{array}$ & 4.1 \\
\hline 5 & $\begin{array}{l}\text { Teaching materials are more practical and can be adjusted to the } \\
\text { ability of students without differentiating SARA }\end{array}$ & 4.5 \\
\hline 6 & $\begin{array}{l}\text { The attractiveness of the display of teaching materials can motivate } \\
\text { students to learn }\end{array}$ & 4.1 \\
\hline $\mathbf{C}$ & \multicolumn{2}{|l|}{ Variable : Effectiveness of time } \\
\hline 1 & The use of teaching materials can streamline learning time & 4.0 \\
\hline 2 & Blended learning that is used can streamline learning time & 4.0 \\
\hline 3 & $\begin{array}{l}\text { The concept of CBT-based learning evaluation used is very effective } \\
\text { for students }\end{array}$ & 4.4 \\
\hline
\end{tabular}

Source : Primary Data, processed (2019) 
Based on the results of the book readability assessment, it could be seen that the thirty students gave a high rating with an average of each dimension measured having an average value of $\geq 4$ to all indicators of book readability. This meant that the macroeconomic theory textbooks that were compiled can be understood well by the users (students). Besides that, it could also be concluded that the book developed has met the readability and practicality criteria, but it still needs to be revised based on user (student) input.

g. Product revision that is the availability of a draft revision of teaching materials resulting from limited test input. After going through the product trial phase on a small sample and also the readability test to students, further revisions were made in accordance with student input so as to produce a textbook of macroeconomic theory of product revision that was ready to be tested on a large group sampl.

\section{Conclusion}

Based on the results of the study, it can be concluded that the research and development of this teaching material has produced macroeconomic theory teaching material that has been validated by 2 expert validators resulting in a decision that teaching material has a very high level of eligibility (88.75\%) with a note that needs to be done revision. After all the revised validator notes were corrected, a small group trial was conducted on 30 students of $\mathrm{C}$ class in economic education in the Macroeconomic Theory course. Based on the results of small group trials, it is known that there was a significant increase before and after using blended learning-based teaching materials. The results of the readability test and the practicality of teaching materials used showed that all the factors of ease for users, effectiveness and time effectiveness had an average value of $\geq 4$, meaning that it was concluded that the developed book had met the readability and practicality criteria according to the user. This research was carried out only to the 7th step, which was to produce a revised draft of teaching material products.

The suggestion in this study is that there needs to be sustainability and improvement of research and development steps in the teaching material of this book in order to improve the teaching material of macroeconomic theory. The next step is the trial of a large sample which in this case is tested on 2 classes of students for 1 semester with an experimental research design and one control class. The end of the meeting will be given a test of learning outcomes and a questionnaire for assessment and an open questionnaire about the teaching material of macroeconomic theory to be revised to produce a revision of the final book before it is proposed to produce more.

\section{References}

Adi, Sugeng Susilo. (2016). Classroom Management untuk Mahasiswa Jurusan Pendidikan. Malang: UB Press.

Borg, Walter.,\& Gall, M.D. (1983). Educational Research : An Introduction (4ed). New York \& London : Longman.

Arikunto, S \& Safruddin A.J, C. (2009). Evaluasi Program Pendidikan. Jakarta: Bumi Aksara.

Dharmawati. (2017). Penggunaan Media E-Learning Berbasis Edmodo Dalam Pembelajaran English For Business. QUERY: Jurnal Sistem Informasi, Vol. 1(1), p 43-49. 
Driscoll, M. (2002). Blended Learning: Let's Get Beyond the Hype. LTI Magazine, (Online), (http://www.ltimagazine.com/ltimagazine /article/articleDetail.jsp), diakses 16 Maret 2019.

Ernawati, I dan Sukardiyono, T. (2017). Uji Kelayakan Media Pembelajaran Interaktif Pada Mata Pelajaran Administrasi Server. Jurnal Elinvo (Electronics, Informatics, and Vocational Education), Vol. 2 (2)

Graham, C.R., Allen, S., and Ure, D. (2003). Blended Learning Environments: A Review of The Research Literature, (Online), http://msed.byu.edu/ipt/graham/vita/ble_litrev.pdf), accessed March 2, 2018.

Hiltz, Roxanne, S., Turoff, \& Murray. (2005). Education Goes Digital: The Evolution of Online Learning and the Revolution in Higher Education. Communications of the ACM. Vol 48(10): p 59-64.

Jones, N. (2006). E-College Wales, a Case Study of Blended Learning. Dalam C. J. Bonk \& C.R. Graham (Eds.), Handbook of Blended Learning: Global Perspectives, Local Designs (hlm. 182-194). San Francisco, CA: Pfeiffer Publishing.

Kadir. (2015). Statistika Terapan : Konsep, Contoh, dan Analisa Data dengan Program SPSS/Lisrel dalam Peneltian. Jakarta : PT Rajagrafindo Persada

Osguthorpe, R., \& Graham, R. (2003). Blended Learning Environments: Definitions and Directions. The Quarterly Review of Distance Education. Vol 4(3), p 227-234.

Sugiyono, (2010). Metode Penelitian Kuantitatif, Kualitatif dan R\&D. Bandung : Alfabeta.

Zulkarnain. (2009). Teknik Penyusunan Bahan Ajar. [Online]. http//zulkarnain.net. [accessed December 5, 2018]. 